\title{
WISP-2 expression in human salivary gland tumors
}

\author{
YUKINAO KOUZU ${ }^{1}$, KATSUHIRO UZAWA $^{1,2}$, MASAKI KATO $^{3}$, MORIHIRO HIGO $^{1}$, YOSHINORI NIMURA ${ }^{3,6}$, \\ KOJI HARADA ${ }^{4}$, TSUTOMU NUMATA ${ }^{5}$, NAOHIKO SEKI ${ }^{3,6}$, MITSUNOBU SATO $^{4}$ and HIDEKI TANZAWA ${ }^{1,2,6}$ \\ ${ }^{1}$ Department of Clinical Molecular Biology, Graduate School of Medicine, Chiba University; ${ }^{2}$ Division of Dentistry and \\ Oral-Maxillofacial Surgery, Chiba University Hospital; ${ }^{3}$ Department of Functional Genomics, Graduate School \\ of Medicine, Chiba University, 1-8-1 Inohana, Chuo-ku, Chiba 260-8670; ${ }^{4}$ The Second Department of Oral and \\ Maxillofacial Surgery, Faculty of Dentistry, Tokushima University, 3-18-15 Kuramoto-cho, Tokushima 770-8504; \\ ${ }^{5}$ Division of Otorhinolaryngology, National Hospital Organization Chiba Medical Center, 4-1-2 Tsubakimori, \\ Chuo-ku, Chiba 260-8606; ${ }^{6}$ Center of Excellence Program in the 21st Century, Graduate School \\ of Medicine, Chiba University, 1-8-1 Inohana, Chuo-ku, Chiba 260-8670, Japan
}

Received November 7, 2005; Accepted December 27, 2005

\begin{abstract}
This study was designed to disclose detailed genetic mechanisms in salivary gland tumors (SGTs) for development of novel independent marker. We constructed an in-house cDNA microarray carrying 2,201 cDNA clones derived from SGT and oral squamous cell carcinoma cDNA libraries. Four cell lines that originated from the SGT-derived cell lines were analyzed using this microarray system. The genes identified by our microarray system were further analyzed at the mRNA or protein expression level in other types of human cancer cell lines and clinical samples (ten normal salivary glands [NSGs], eleven pleomorphic adenomas, ten adenoid cystic carcinomas and three adenocarcinomas). Two up-regulated genes and six down-regulated genes were identified in common when compared with the control RNA. Of the up-regulated genes, WISP-2, which plays an important role in breast carcinogenesis, was selected for further analyses. We found a higher expression of the WISP-2 gene in the SGT-derived cell lines compared with other types of human cancer cell lines. Furthermore, WISP-2 mRNA and protein expression levels in NSGs were significantly higher than those in SGTs. These results suggest that WISP-2 could be a reliable independent marker and that down-regulation or loss of the WISP-2 gene may be associated with the development of SGTs.
\end{abstract}

\section{Introduction}

Tumors of the salivary glands account for $5 \%$ of all neoplasms of the head and neck $(1,2)$. These tumors originate primarily

Correspondence to: Dr Katsuhiro Uzawa, Graduate School of Medicine, Chiba University, 1-8-1 Inohana, Chuo-ku, Chiba 2608670, Japan

E-mail: uzawak@faculty.chiba-u.jp

Key words: WISP-2, cDNA microarray, real-time quantitative RT-PCR, Western blot, immunohistochemistry in the parotid gland, occasionally in the submandibular and intraoral glands, and rarely in the sublingual gland $(1,3)$. Salivary gland tumors (SGTs) are both benign and malignant.

The prognosis of malignant SGTs is frequently unpredictable. SGTs are slow-growing but relentless tumors, with a relatively favorable 5-year survival rate but a worse long-term outlook. Although malignant SGTs have a proclivity for invading nerves, these tumors infrequently spread via the lymphatic system. These tumors also have a protracted clinical course with local recurrences, hematogenous metastases, and a poor response to classic chemotherapeutic approaches. After surgery and radiation therapy for patients with malignant SGTs, the disease-specific survival at 15 years is approximately $40 \%$ (4).

Some markers of tumor progression, invasiveness, and prognosis are p27 (Kipl), a cyclin-dependent kinase inhibitor, the oncoproteins $\mathrm{Bcl}-2$ and $\mathrm{Bax}$, the tumor-suppressor gene product $p 53$, terminal deoxynucleotidyltransferase-mediated nick end-labeling staining, and cell cycle antigen $\mathrm{Ki}-67$ (5-7). Studies of these markers in SGTs generally focused on differentiating various benign and malignant tumors. It would be helpful to discover reliable biologic markers to manage patients with malignant SGTs.

The cDNA microarray serves as a useful tool for comparing the expression levels of genes $(8,9)$ that originate from pathologically changed tissues with those of genes that originate from normal tissues. In addition, the changes in each disease stage can be used to follow disease progression, which is useful for predicting the response to medical treatment. The emerging technology of cDNA microarray allows comparative analysis of mRNA expression of thousands of genes in parallel (10). Several studies have already demonstrated the usefulness of this technique for identifying novel cancer-related genes and classifying human cancer at the molecular level (11-13).

In this study, we first produced a specialized in-house cDNA microarray of oral squamous cell carcinomas (OSCCs) and SGTs. We have already used an in-house cDNA microarray technique to assess the gene expression profile of SGTs. Several genes identified in the present study may be involved 
in salivary gland tumorigenesis and may be potential clinical biomarkers that can improve early diagnosis and as such are potential novel therapeutic targets.

\section{Materials and methods}

Tissue specimens and cell lines. Tissue specimens were obtained at the time of surgical resection at Chiba University Hospital. We obtained written informed consent from all patients before the start of the study. All clinical specimens remained anonymous to ensure patient privacy. Five specimens of normal submandibular gland tissue and three of ACCs were used to construct the cDNA library. In addition, four SGT-derived cell lines, including HSG, HSG-AZA1, HSGAZA3, and HSY were used. A neoplastic human salivary intercalated duct cell line (HSG) and its derivatives, HSG with a myoepithelial cell phenotype (HSG-AZA1) and HSG with an acinar cell phenotype (HSG-AZA3), induced by 5-aza-2'-dC treatment of HSG cells, were already reported (14). HSY was based on immunocytochemical characteristics in morphology, and it was thought that it occurred from intercalated ducts or acinus domain (15). These cell lines were cultured in Dulbecco's modified Eagle medium/F-12 HAM (DMEM/F12) (Sigma-Aldrich Co., St. Louis, MO), and incubated in a medium containing collagenase $\mathrm{P}$ (Boehringer Mannheim, Mannheim, Germany) $100 \mathrm{mU} / \mathrm{ml}$ (10 ml of medium total/ preparation) for $2 \mathrm{~h}$ at $37^{\circ} \mathrm{C}$. The medium was collected, centrifuged at $500 \mathrm{x} \mathrm{g}$ for $10 \mathrm{~min}$, and the cells were washed 3 times with medium. After a final washing, the cells were plated in DMEM/F12 containing 10\% fetal bovine serum (Sigma) and 50 units/ml penicillin and streptomycin (Sigma) (16).

RNA preparation and construction of the cDNA library. Total RNA was extracted from the tissue specimens described previously using the Trizol reagent (Invitrogen Corp., Carlsbad, CA), according to the manufacturer's instructions. The oligo-capped cDNA library was constructed using $1000 \mu \mathrm{g}$ of RNA derived from normal submandibular glands and ACCs (16).

DNA sequencing and bioinformatics analysis for data management. Bacterial culture and plasmid extractions were performed in a 96-well format (Multiscreen Assay Systems, Millipore, Bedford, MA). The sequencing reactions were performed in 9600 thermal reactors (Applied Biosystems, Foster City, CA) using a dye terminator cycle sequencing kit (Applied Biosystems). The reaction products were analyzed using the ABI-3700 DNA sequencer (Applied Biosystems) and partial 5'-end sequences were obtained for each clone. The cDNA clones were clustered according to their 5'-one-pass sequence using Dynaclust software (Dynacom, Chiba, Japan) with a default parameter. The nucleotide sequences were compared with the National Center for Biotechnology Information nucleotide databases using the Basic Local Alignment Search Tool (BLAST) programs (http://www.ncbi. nlm.nih.gov/BLAST/) (17).

Preparation of in-house cDNA microarray. A total of 2,016 cDNA clones were picked up from the oligo-capped cDNA library, and their 5'-end nucleotide sequences determined. Excluding overlapping clones, 778 distinct genes were selected. In addition, 1,423 nonidentical genes derived from the cDNA library of a mixture of OSCC and normal oral mucosa that had already been fixed in our laboratory was included in the production of the microarray (17). The cDNA microarrays consisting of these 2,201 cDNA clones were produced as previously described $(8,18)$. Briefly, polymerase chain reaction (PCR)-amplified cDNA products were mixed with nitrocellulose in dimethyl sulfoxide just before printing and then spotted onto carbodiimide-coated glass slides (Nisshinbo Industries, Tokyo, Japan) using a robot SPBIO-2000 (Hitachi Software Engineering Co., Yokohama, Japan). The microarray also included cDNAs of housekeeping genes such as human B-actin and glyceraldehyde-3-phosphate dehydrogenase (GAPDH), to serve as internal controls. A luciferase gene from Photinus pyralis was used as a negative control (17).

Microarray procedure. Total RNA was extracted from the four SGT-derived cell lines, HSG, HSG-AZA1, HSG-AZA3, and HSY. Universal Human Reference RNA (UHRR) (Stratagene, La Jolla, CA) was used as the control. Microarray analysis was performed as described previously (18). Briefly, Cy3dUTP or Cy5-dUTP (Amersham Biosciences, Little Chalfont, Buckinghamshire, UK) was incorporated during reverse transcription of the $20 \mu \mathrm{g}$ of total RNA using SuperScript II Rnase $\mathrm{H}^{-}$Reverse Transcriptase (Invitrogen) and oligo(dT) primer (Sigma Genosys, Ishikari, Japan). In each experiment, fluorescent cDNA probes (Cy3- or Cy5-labeled) were prepared from $2 \mu \mathrm{g}$ of the experimental mRNA sample isolated from each cell line and $2 \mu \mathrm{g}$ of the control mRNA sample (Cy5- or Cy3-labeled). Different fluorescence-labeled probes from the cell line and the control sample were mixed and applied to the microarray, followed by incubation at $65^{\circ} \mathrm{C}$ overnight in a humid atmosphere. The fluorescent images of the hybridized microarrays were scanned with a fluorescent laser confocal slide scanner (ScanArray Lite, Packard BioChip Technologies LLC, Billerica, MA). Images were analyzed with QuantArray software version 3.0 (Packard BioChip Technologies LLC), according to the manufacturer's instructions. To control for labeling differences, experiments were carried out in duplicate in which the fluorescent dyes were switched during cDNA synthesis for the SGT-derived cell lines and UHRR (Stratagene). Each pair of probes was hybridized to a separate microarray.

Analysis for $m R N A$ and protein expression of WISP-2 in vitro. Of the up-regulated genes identified by microarray analysis, WISP-2 was selected for further analyses, such as real-time quantitative RT-PCR (qRT-PCR) and Western blotting. Total RNAs obtained from the SGT-derived cell lines and other types of human cancer cell lines, including OSCC, hepatocarcinoma (HC), bladder cancer (BC), malignant melanoma (MM), lung cancer (LC), esophageal cancer (EC), and gastric cancer (GC) and normal fibroblast (NF) were reverse transcribed as described above. qRT-PCR was performed to evaluate expression levels of WISP-2 mRNA in the above mentioned cell lines using a LightCycler FastStart DNA Master SYBR Green 1 kit (Roche Diagnostics GmbH, Mannheim, Germany), according to the procedure provided by the 
Table I. Up-regulated and down-regulated gene in HSG, HSG-AZA1, HSG-AZA3 and HSY.

\begin{tabular}{|c|c|c|c|}
\hline Unigene number & Definition & $\begin{array}{l}\text { Chromosome } \\
\text { location }\end{array}$ & $\begin{array}{l}\text { Relative mRNA } \\
\text { expression ratio }\end{array}$ \\
\hline \multicolumn{4}{|l|}{ Up-regulated genes } \\
\hline Hs. 194679 & WNT1 inducible signaling pathway protein 2 (WISP-2) & 20q12-q13.1 & 4.32 \\
\hline Hs. 1369 & Decay accelerating factor for complement (CD55, DAF) & $1 \mathrm{q} 32$ & 5.70 \\
\hline \multicolumn{4}{|c|}{ Down-regulated genes } \\
\hline Hs. 300697 & Immunoglobulin heavy constant mu & $14 \mathrm{q} 32.33$ & 0.1 \\
\hline Hs. 77326 & Insulin-like growth factor-binding protein 3 & $7 \mathrm{p} 13-12$ & 0.15 \\
\hline Hs. 401145 & $\mathrm{~T}$ cell receptor beta chain & $4 \mathrm{p} 11$ & 0.25 \\
\hline Hs. 272499 & Dehydrogenase/reductase member 2 & $14 q 11.12$ & 0.25 \\
\hline Hs. 283565 & Fos-like antigen 1 & $11 \mathrm{q} 13$ & 0.32 \\
\hline Hs. 297753 & Human vimentin gene & 10 p13 & 0.36 \\
\hline
\end{tabular}

manufacturer. The primer sequences used to analyze WISP-2 mRNA expression were 5'-ATGGCAGAGGTGCAAGACC TAGTC-3' (nucleotides 1083-1106) and 5'-GGATGAAGA GAAGGCACACAGAGA-3' (nucleotides 1315-1338). The sequence of specific primers was checked before use to avoid amplification of genomic DNA or pseudogenes by the Primer3 program (available at http://www-genome.wi.mit. edu/cgi-bin/primer/primer3_www.cgi). Amplified products were analyzed by $3 \%$ agarose gel electrophoresis to ascertain their size and purity. The PCR reactions using a LightCycler (Roche) apparatus were carried out in a final volume of $20 \mu 1$ of a reaction mixture consisting of $2 \mu 1$ of FirstStart DNA Master SYBR Green I mix (Roche), $3 \mathrm{mM}$ $\mathrm{MgCl}_{2}$, and $0.2 \mu 1$ of the primers, according to the manufacturer's instructions. The reaction mixture then was loaded into glass capillary tubes and subjected to an initial denaturation at $95^{\circ} \mathrm{C}$ for $10 \mathrm{~min}$, followed by 45 rounds of amplification at $95^{\circ} \mathrm{C}(10 \mathrm{sec})$ for denaturation, $61^{\circ} \mathrm{C}(10 \mathrm{sec})$ for annealing, and $72^{\circ} \mathrm{C}$ for extension, with a temperature slope of $20^{\circ} \mathrm{C} / \mathrm{sec}$, performed in the LightCycler. The transcript amount for the WISP-2 gene was estimated from the respective standard curves and normalized to the GAPDH transcript amount determined in corresponding samples. The statistical significance of the expression levels of WISP-2 mRNA between two groups (SGT-derived cell lines vs. other cell lines) was calculated with the Mann-Whitney's U-test. $\mathrm{P}<0.05$ was considered significant.

We also evaluated the protein expression status by Western blot analysis. Briefly, SGT-derived cell lines and SCC-derived cell lines were lysed in lysis buffer $[10 \mathrm{mM}$ Tris base ( $\mathrm{pH} 8.0)$, $400 \mathrm{mM} \mathrm{NaCl}, 3 \mathrm{mM} \mathrm{MgCl} 2,0.5 \%$ NP-40, $100 \mathrm{mM}$ phenylmethylsulfonyl fluoride, and $0.01 \%$ protease inhibitor cocktail (Sigma) ] at $4^{\circ} \mathrm{C}$ for $10 \mathrm{~min}$. Cell extracts were centrifuged for $15 \mathrm{~min}$ at $4^{\circ} \mathrm{C}$. The protein concentration was determined in the supernatant. Protein extracts were electrophoresed on $11 \%$ sodium dodecyl sulfate-polyacrylamide electrophoresis gels, transferred to PVDF membranes (Bio-Rad Laboratories, Hercules, CA), and blocked for $1 \mathrm{~h}$ at room temperature in 5\% skim milk. Immunoblot PVDF membranes were washed with $0.1 \%$ Tween-20 in TBS (TBS-T) 5 times, and $2 \mu \mathrm{g} / \mathrm{ml}$ affinity- purified goat antihuman WISP-2 polyclonal antibody (Santa Cruz Biotechnology, Santa Cruz, CA) was added directly to the TBS-T solution for $2 \mathrm{~h}$ at room temperature. PVDF membranes were washed again and incubated with a 1:10000 of horseradish peroxidase-conjugated antigoat IgG Ab (Santa Cruz Biotechnology) as a secondary antibody for $20 \mathrm{~min}$ at room temperature. Finally, membranes were incubated with ECL+ horseradish peroxidase substrate solution included in the ECL+ kit (Amersham), and immunoblotting was visualized by exposing the membrane to Hyperfilm (Amersham) $(16,19)$.

Analysis for mRNA and protein expression of WISP-2 in vivo. The mRNA and protein expression status of WISP-2 in clinical samples were examined. Surgical specimens of five SGTs including three ACCs and two ACs, and five NSGs were selected for qRT-PCR analysis. Total RNAs were isolated from them using Trizol reagent (Invitrogen). The statistical significance of the expression levels of WISP-2 mRNA between two groups was calculated with the Mann-Whitney's U-test. $\mathrm{P}<0.05$ was considered significant.

Immunohistochemical staining was performed on 10 NSGs and 24 SGTs (11 PAs, 10 ACCs and 3 ACs). Briefly, the 4- $\mu \mathrm{m}$ paraffin-embedded specimens were deparaffinized and hydrated. The slides were treated with endogenous peroxidase in $0.3 \%$ hydrogen peroxide for $30 \mathrm{~min}$, and the sections were blocked for $2 \mathrm{~h}$ at room temperature with $1.5 \%$ blocking serum (Santa Cruz Biotechnology) in phosphate-buffered saline (PBS) before reaction with anti-human WISP-2 polyclonal antibody (Santa Cruz Biotechnology) at a dilution of $1: 100$. The sections then were incubated with primary antibody and nonimmune control antibody for $3 \mathrm{~h}$ at room temperature in a moist chamber. After incubation, the samples were incubated with biotinylated antigoat $\operatorname{IgG}$ and peroxidase-conjugated streptavidin. The peroxidase reaction was performed using a 3,3'-diaminobenzidine tetrahydrochloride (Dako Japan Inc., Kyoto, Japan). Then the slides were counterstained with hematoxylin, dehydrated in graded ethanol, cleaned in xylene, and mounted. As a negative control, duplicate sections were immunostained without exposure to primary antibodies $(16,19)$. 
Table II. Primer pairs for RT-PCR analysis.

\begin{tabular}{lccc}
\hline Gene name & Forward primer & Reverse primer & Size \\
\hline WISP-2 & 5'-ATGGCAGAGGTGCAAGACCTAGTC-3' & 5'-TCTCTGTGTGCCTTCTCTTCATCC-3' & 258 \\
GAPDH & 5'-CATCTCTGCCCCCTCTGCTGA-3' & 5'-GGATGACCTTGCCCACAGCCT-3' & 305 \\
\hline
\end{tabular}

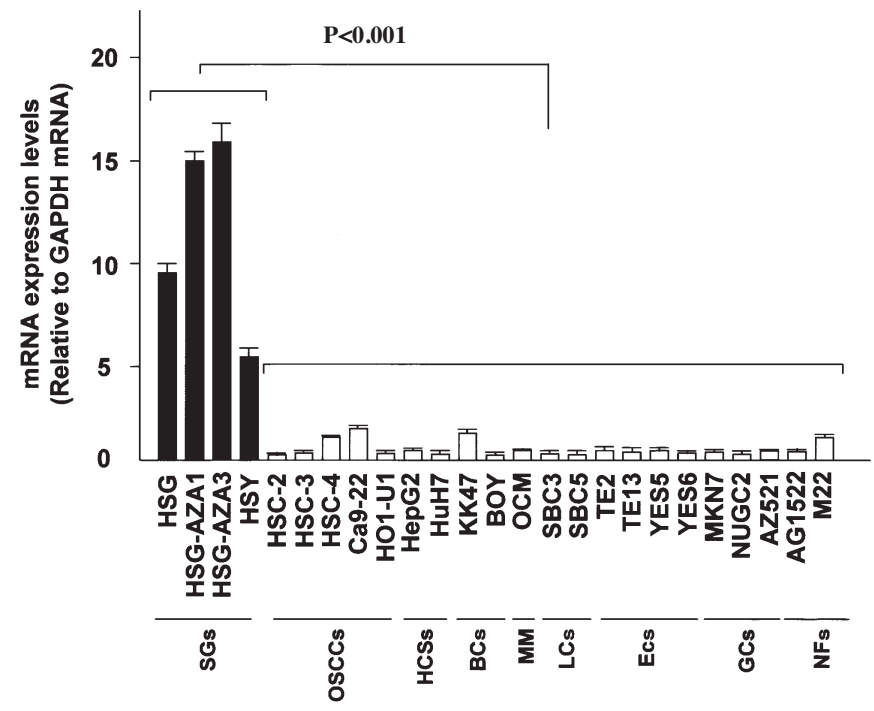

Figure 1. Quantification of mRNA levels in SGT-derived cell lines by qRTPCR. The WISP-2 expression levels in SGT-derived cell lines are significantly higher than in other types of human cancer cell lines [OSCC, hepatocarcinoma (HC), bladder cancer (BC), malignant melanoma (MM), lung cancer (LC), esophageal cancer (EC) and gastric cancer (GC) $(\mathrm{P}<0.001)] . \mathrm{P}<0.05$ is considered significant. The data are expressed as the mean $\pm \mathrm{SD}$.

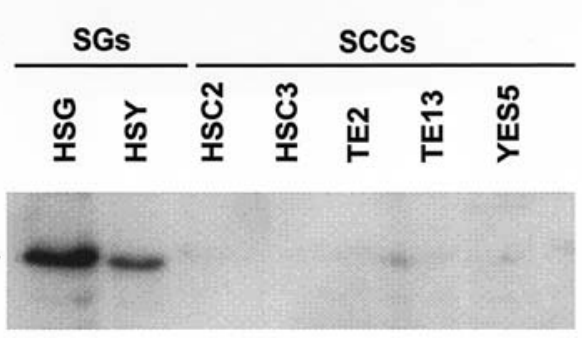

WISP-2

Figure 2. Representative results of expression of WISP-2 protein in SGTderived cell lines. To investigate WISP-2 protein expression in HSG and HSY, we performed Western blot analysis. The size of the WISP-2 protein band is $26 \mathrm{kDa}$.

\section{Results}

Construction of the cDNA library and in-house cDNA microarray. We constructed a full-length-enriched cDNA library using the oligo-capping method (18) with RNA from clinical samples as described previously. We first determined the 5'-end sequence of 2,016 cDNA clones from the library and the nucleotide sequences were compared with the GenBank nucleotide databases using BLAST. To evaluate the cDNA

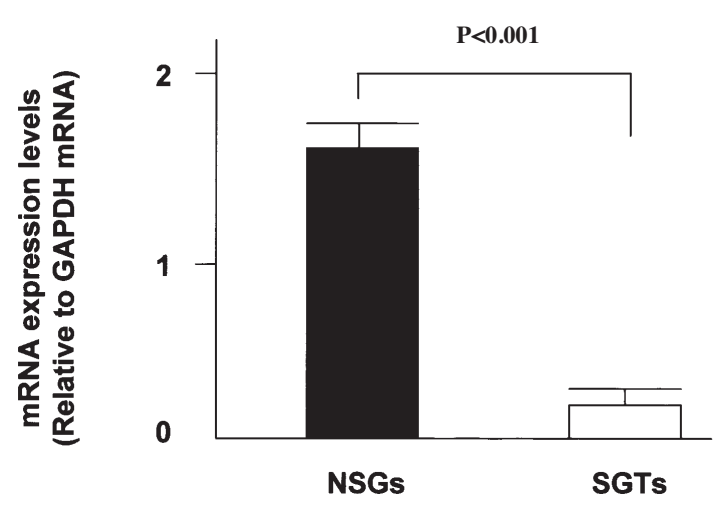

Figure 3. Comparison of WISP-2 mRNA expression levels between NSGs and SGTs using qRT-PCR. The ratios (WISP-2/GAPDH) for NSGs $(n=5)$ and SGTs $(\mathrm{n}=5)$ ranged from 0.43 to 2.41 (median, 1.18) and from 0.01 to 0.31 (median, 0.07). The WISP-2 expression levels in NSGs were significantly higher than those in SGTs $(\mathrm{P}=0.009)$. A probability of $\mathrm{P}<0.05$ is considered significant.

library, the nucleotide sequences of 96 randomly chosen clones were investigated. The results showed that $65 \%$ of the cDNA clones were full length. The average length of the cDNA insert was approximately 1.6 kilobase pairs. The 778 distinct clones were selected from the sequence information. In addition, 1,423 nonidentical genes derived from the cDNA library of a mixture of OSCC and normal oral mucosa that had already been fixed in our laboratory was included in the production of the microarray. The cDNA microarrays consisting of these 2,201 cDNA clones were produced as previously described. The in-house cDNA microarray reflects characteristics of SGTs, NSGs, OSCC, and oral mucosa.

cDNA microarray analysis. To identify the genes associated with SGTs, we analyzed the gene profiles of four SGT-derived cell lines (HSG, HSG-AZA1, HSG-AZA3, and HSY) using our in-house cDNA microarray, which contains 2,201 independent cDNA clones. The microarray was subsequently hybridized with cDNA probes labeled with fluorochromes. Eight individual hybridization experiments were performed, and fluorescent dyes for the probes were exchanged in half of the experiments. Microarray analysis showed that two genes were commonly up-regulated 2-fold or more and six genes were commonly down-regulated 0.5 -fold or less in these SGTderived cell lines, compared to the status of the UHRR control genes (Stratagene). Among them, we identified eight genes that were expressed in common (Table I).

Analyses of $m R N A$ and protein expression of WISP-2 in vitro. The qRT-PCR analysis data were matched to mRNA 

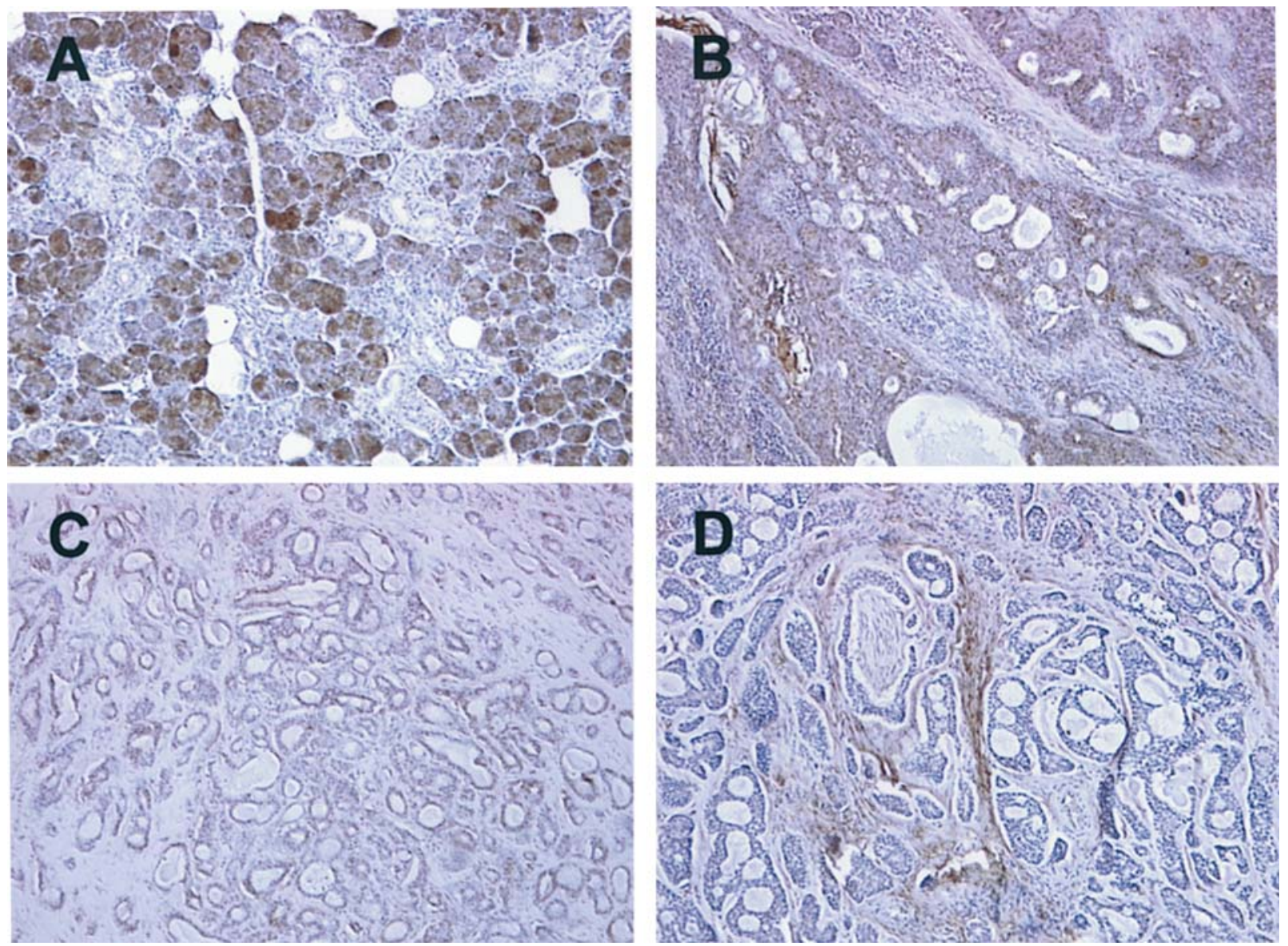

Figure 4. Immunohistochemical staining of WISP-2. (A) NSGs show strong immunoreaction of the acinar cell. (B) A moderate staining for WISP-2 is evident in a PA case. (C) A significant lower WISP-2 expression is seen in an AC case. (D) Negative staining for WISP-2 in tumor cells of ACC. Original magnification $\mathrm{x} 200$.

expression studied in the microarray analysis. WISP-2 and GAPDH primer pair and the RT-PCR conditions are summarized in Table II. The mRNA expression of WISP-2 was significantly reduced in other types of human cancer cell lines (HC, BC, MM, LC, EC, and GC) and NF. The mRNA expression levels were normalized to GAPDH. Fig. 1 shows a significant increase in the expression of WISP-2 in all SGTderived cell lines examined compared with other cancer cell lines used as controls. The WISP-2 expression levels in SGTderived cell lines were significantly higher than other cancer cell lines $(\mathrm{P}<0.001)$.

To investigate WISP-2 protein expression in SGT-derived cell lines and SCC-derived cell lines, we performed Western blot analysis. Fig. 2 shows representative results of Western blot analysis for WISP-2 protein expression. The size of the band was $26 \mathrm{kDa}$. A significant increase in WISP-2 expression was observed in the SGT-derived cell lines examined compared with the SCC-derived cell lines. Taken together, mRNA and protein analyses indicated that both transcription and translation products of this molecule were highly expressed in SGT-derived cell lines.

Analyses of mRNA and protein expression of WISP-2 in vivo. To examine WISP-2 mRNA expression in vivo, we analyzed WISP-2 mRNA expression levels in five NSGs and five SGTs using qRT-PCR. The ratios (WISP-2/GAPDH) for NSGs and
SGTs ranged from 0.43 to 2.41 (median, 1.18) and from 0.01 to 0.31 (median, 0.07, Fig. 3). The WISP-2 expression levels in NSGs were significantly higher than those in SGTs $(\mathrm{P}=0.009$, Fig. 3).

To investigate the distribution of WISP-2 protein expression in vivo, we performed immunohistochemical staining of the protein in 34 clinical samples, including 24 SGTs (11 PAs, 10 ACCs and 3 ACs) and 10 NSGs. NSGs revealed strong immunoreaction of the acinar cell (Fig. 4A). A moderate staining for WISP-2 was evident in a PA case (Fig. 4B). A significant lower WISP-2 expression was seen in an AC case (Fig. 4C). Negative staining for WISP-2 in tumor cells of ACC was observed (Fig. 4D). No staining was observed in a control section in which primary antibody was replaced by $1 \%$ bovine serum albumin in PBS (data not shown).

\section{Discussion}

The prognoses of malignant SGTs are frequently unpredictable. These tumors are slow growing but relentless, with a relatively favorable 5-year survival rate but a worse long-term outlook (20). It would be helpful to discover reliable biologic makers to manage patients with malignant SGTs. cDNA microarray systems have been used to identify genes in malignant tumors, such as malignant lymphoma (21), hepatocellular carcinoma $(22,23)$, breast $(24,25)$, prostate $(26)$, colorectal 
(27), esophageal $(28,29)$, gastric $(30)$, and head and neck cancer $(17,31,32)$, and ovarian carcinoma (33). We produced an in-house cDNA microarray that contains 1,423 cDNA clones derived from the OSCC cDNA library and 778 cDNA clones derived from the SGT cDNA library. To identify the genes associated with the development of SGT, the in-house cDNA microarray was used to analyze gene expression profiles of four SGT-derived cell lines (HSG, HSG-AZA1, HSG-AZA3, and HSY). Two up-regulated genes and six down-regulated genes were identified in common when compared with the UHRR (Stratagene). Of the up-regulated genes, WISP-2, which plays an important role in breast carcinogenesis, was selected for further analyses by qRTPCR, and Western blotting. Consequently, we found higher expression of the WISP-2 gene in the SGT-derived cell lines compared to other types of human cancer cell lines derived from OSCC, HC, BC, MM, LC, EC, and GC. WISP-2 mRNA and protein expression levels in NSGs were significantly higher than those in SGTs.

WISP-2 is a member of the connective tissue growth factor/ cysteine-rich 61/neuroblastoma-overexpressed (CCN) family and is coming under increasing scrutiny in cancer research (34). Two family members (WISP-1 and WISP-3), closely related to the WISP-2 gene, were identified and described in humans (35). Nucleotide and protein sequence alignment studies have demonstrated a 30-40\% sequence homology within the WISP genes (WISP-1, WISP-2, and WISP-3). Their modular architecture is similar except in their C-terminal domain, which is absent in the WISP-2 gene (35). The functional significance of this newly identified molecule has not yet been established. Increasing evidence suggests that WISP-2 proteins may play an important role in the evolution of various cancers (35), and the finding that expression of WISP-2 can be modulated by 17ß-estradiol (Banerjee SK, 5th World Congress on Advances in Oncology and 3rd International Symposium on Molecular Medicine, Athens, Greece, 2000), a natural estrogen that modulates breast cancer cell proliferation (36) and that is associated with several types of human and animal cancers (37-39), further enhances interest in mitogenic and/or carcinogenic potential of the molecule. The gene for human WISP-2 was localized to chromosome 20q12-20q13, at a region frequently amplified and associated with poor prognosis in node-negative breast and colon cancer, suggesting the presence of one or more oncogenes at this locus $(34,35,40,41)$. In contrast, the finding that WISP-2 is underexpressed in human colon tumors suggests potential tumor-suppressive properties (35).

A recent report on $r$ Cop -1 , the rat orthologue of WISP-2, described the loss of expression of this gene after cell transformation, suggesting it may be a negative regulator of growth in the cell line $(42,43)$. Although the mechanism by which WISP-2 RNA expression is down-regulated during malignant trans-formation is unknown, the reduced expression of WISP-2 in colon tumors and cell lines suggests that it may function as a tumor suppressor (35). Thus, the status of WISP-2 is likely to differ from tumor to tumor. To resolve the inconsistency regarding the functional relevance of WISP-2, its expression was evaluated in SGT. Considering the possible complexity of WISP-2 function in different tumors, it seems logical that it may not be a universal positive regulator of cell proliferation. Further detailed studies are required to resolve this issue.

In conclusion, we constructed an in-house cDNA microarray carrying 2,201 cDNA clones derived from oligo-capped SGT and OSCC cDNA libraries. Using the microarray, the most overexpressed gene in SGT-derived cell lines relative to the control was WISP-2 together with certain genes that are selectively overexpressed in SGT-derived cell lines relative to other types of carcinoma cell lines. In addition, WISP-2 was differentially expressed in NSGs and SGTs. The expression of WISP-2 was significantly higher in NSGs compared to SGTs. Therefore, we suggest that WISP-2 is a reliable independent marker and that down-regulation or loss of the WISP-2 gene may be associated with the development of SGTs.

\section{Acknowledgements}

This study was supported by a Grant-in-Aid Scientific Research (No. 15659473) from the Ministry of Education, Culture, Sports, Science and Technology of Japan.

\section{References}

1. Heikinheimo KA, Laine MA, Ritvos OV, Voutilainen RJ, Hogan BL, Leivo IV and Heikinheimo AK: Bone morphogenetic protein-6 is a marker of serous acinar cell differentiation in normal and neoplastic human salivary gland. Cancer Res 59: 5815-5821, 1999

2. Ellis GL and Auclair PL: Tumors of the salivary glands. In: Atlas of Human Pathology, Fascicle 17. Armed Forces Institute of Pathology, Washington, DC, 1996.

3. Seifert G, Brocheriou C, Cardesa A and Eveson JW: WHO International Histological Classification of Tumors. Tentative Classification of Tumors Salivary Gland Tumors. Pathol Res Pract 186: 555-581, 1990.

4. Fordice J, Kershaw C, El-Naggar A and Goepfert H: Adenoid cystic carcinoma of the head and neck: predictors of morbidity and mortality. Arch Otolaryngol Head Neck Surg 125: 149-152, 1999.

5. Francioso F, Carinci F, Tosi L, Scapoli L, Pezzetti F, Passerella E, Evangelisti R, Pastore A, Pelucchi S, Piattelli A, Rubini C, Fioroni M, Carinci $P$ and Volinia S: Identification of differentially expressed genes in human salivary gland tumors by DNA microarrays. Mol Cancer Ther 1: 533-538, 2002.

6. Choi CS, Choi G, Jung KY, Choi JO and Chae YS: Low expression of p27 (Kip1) in advanced mucoepidermoid carcinomas of head and neck. Head Neck 23: 292-297, 2001.

7. Yin HF, Okada N and Takagi M: Apoptosis and apoptoticrelated factors in mucoepidermoid carcinoma of the oral minor salivary glands. Pathol Int 50: 603-609, 2000.

8. Schena M, Shalon D, Davis RW and Brown PO: Quantitative monitoring of gene expression patterns with a complementary DNA microarray. Science 270: 467-470, 1995.

9. Derisi J, Penland L, Brown PO, Bittner ML, Meltzer PS, Ray M, Chen Y, Su YA and Trent JM: Use of a cDNA microarray to analyse gene expression patterns in human cancer. Nat Genet 14: 457-460, 1996.

10. Golub TR, Slonim DK, Tamayo P, Huard C, Gaasenbeek M, Mesirov JP, Coller H, Loh ML, Downing JR, Caligiuri MA, Bloomfield CD and Lander ES: Molecular classification of cancer: class discovery and class prediction by gene expression monitoring. Science 286: 531-537, 1999.

11. Bittner M, Meltzer P, Chen Y, Jiang Y, Seftor E, Hendrix M, Radmacher M, Simon R, Yakhini Z, Ben-Dor A, Sampas N, Dougherty E, Wang E, Marincola F, Gooden C, Lueders J, Glatfelter A, Pollock P, Carpten J, Gillanders E, Leja D, Dietrich K, Beaudry C, Berens M, Alberts D, Sondak V, Hayward $\mathrm{N}$ and Trent J: Molecular classification of cutaneous malignant melanoma by gene expression profiling. Nature 406: 536-540, 2000.

12. Khan J, Simon R, Bittner M, Chen Y, Leighton SB, Pohida T, Smith PD, Jiang Y, Gooden GC, Trent JM and Meltzer PS: Gene expression profiling of alveolar rhabdomyosarcoma with cDNA microarrays. Cancer Res 58: 5009-5013, 1998. 
13. Luo J, Duggan DJ, Chen Y, Sauvageot J, Ewing CM, Bittner ML, Trent JM and Isaacs WB: Human prostate cancer and benign prostatic hyperplasia: molecular dissection by gene expression profiling. Cancer Res 61: 4683-4688, 2001.

14. Aladib W, Yoshida H and Sato M: Effect of epidermal growth factor on the cellular proliferation and phenotype of a neoplastic human salivary intercalated duct cell line or its derivatives. Cancer Res 50: 7650-7661, 1990.

15. Yanagawa T, Hayashi Y, Nagamine S, Yoshida H, Yura Y and Sato M: Generation of cells with phenotypes of both intercalated duct-type and myoepithelial cells in human parotid gland adenocarcinoma clonal cells grown in athymic nude mice. Virchows Arch B Cell Pathol Incl Mol Pathol 51: 187-195, 1986.

16. Kasamatsu A, Uzawa K, Shimada K, Shiiba M, Otsuka Y, Seki N, Abiko Y and Tanzawa H: Elevation of galectin-9 as an inflammatory response in the periodontal ligament cells exposed to Porphylomonas gingivalis lipopolysaccharide in vitro and in vivo. Int J Biochem Cell B 37: 397-408, 2005.

17. Moriya T, Seki N, Shimada K, Kato M, Yakushiji T, Nimura Y, Uzawa $\mathrm{K}$, Takiguchi $\mathrm{M}$ and Tanzawa $\mathrm{H}$ : In-house cDNA microarray analysis of gene expression profiles involved in SCC cell lines. Int J Mol Med 12: 429-435, 2003.

18. Maruyama K and Sugano S: Oligo-capping: a simple method to replace the cap structure of eukaryotic mRNAs with oligoribonucleotides. Gene 138: 171-174, 1994.

19. Endo Y, Uzawa K, Mochida Y, Shiiba M, Bukawa H, Yokoe H and Tanzawa H: Sarcoendoplasmic reticulum $\mathrm{Ca}(2+)$ ATPase type 2 downregulated in human oral squamous cell carcinoma. Int J Cancer 110: 225-231, 2004.

20. Cho KJ, Lee SS and Lee YS. Proliferating cell nuclear antigen and c-erbB-2 oncoprotein expression in adenoid cystic carcinomas of the salivary glands. Head Neck 21: 414-419, 1999.

21. Alizadeh AA, Eisen MB, Davis RE, Ma C, Lossos IS, Rosenwald A, Boldrick JC, Sabet H, Tran T, Yu X, Powell JI, Yang L, Marti GE, Moore T, Hudson J Jr, Lu L, Lewis DB, Tibshirani R, Sherlock G, Chan WC, Greiner TC, Weisenburger DD, Armitage JO, Warnke R, Levy R, Wilson W, Grever MR, Byrd JC, Botstein D, Brown PO and Staudt LM: Distinct types of diffuse large B-cell lymphoma identified by gene expression profiling. Nature 403: 503-511, 2000.

22. Okabe H, Satoh S, Kato T, Kitahara O, Yanagawa R, Yamaoka Y, Tsunoda T, Furukawa Y and Nakamura Y: Genome-wide analysis of gene expression in human hepatocellular carcinomas using cDNA microarray: identification of genes involved in viral carcinogenesis and tumor progression. Cancer Res 61: 2129-2137, 2001

23. Shirota Y, Kaneko S, Honda M, Kawai HF and Kobayashi K: Identification of differentially expressed genes in hepatocellular carcinoma with cDNA microarrays. Hepatology 33: 832-840, 2001.

24. Martin KJ, Kritzman BM, Price LM, Koh B, Kwan CP, Zhang X, Mackay A, O'Hare MJ, Kaelin CM, Mutter GL, Pardee AB and Sager R: Linking gene expression patterns to therapeutic groups in breast cancer. Cancer Res 60: 2232-2238, 2000.

25. Van't Veer LJ, Dai H, van de Vijver MJ, He YD, Hart AA, Mao M, Peterse HL, van der Kooy K, Kerkhoven RM, Witteveen AT, Marton MJ, Schreiber GJ, Roberts C, Linsley PS, Bernards R and Friend SH: Gene expression profiling predicts clinical outcome of breast cancer. Nature 415: 530-536, 2002.

26. Chaib H, Cockrell EK, Rubin MA and Macoska JA: Profiling and verification of gene expression patterns in normal and malignant human prostate tissues by cDNA microarray analysis. Neoplasia 3: 43-52, 2001.

27. Kitahara O, Furukawa Y, Tanaka T, Kihara C, Ono K, Yanagawa R, Nita ME, Takagi T, Nakamura Y and Tsunoda T: Alterations of gene expression during colorectal carcinogenesis revealed by cDNA microarrays after laser-capture microdissection of tumor tissues and normal epithelia. Cancer Res 61: 3544-3549, 2001.
28. Sebastian JL, Rigberg DA, Shrivatsan E, Revasova E, McFadden DM and Levingston EH: The use of large-scale cDNA analysis to profile differential gene expression in KYSE 410 human esophageal cancer cells after irradiation. Bull Exp Biol Med 130: 882-885, 2000.

29. Kihara C, Tsunoda T, Tanaka T, Yamana H, Furukawa Y, Ono K, Kitahara O, Zembutsu H, Yanagawa R, Hirata K, Takagi T and Nakamura Y: Prediction of sensitivity of esophageal tumors to adjuvant chemotherapy by cDNA microarray analysis of geneexpression profiles. Cancer Res 61: 6474-6479, 2001.

30. Mori M, Mimori K, Yoshikawa Y, Shibuta K, Utsunomiya T, Sadanaga N, Tanaka F, Matsuyama A, Inoue H and Sugimachi K: Analysis of the gene-expression profile regarding the progression of human gastric carcinoma. Surgery 131: 39-47, 2002.

31. Leethanakul C, Patel V, Gillespie J, Pallente M, Ensley JF, Koontongkaew S, Liotta LA, Emmert-Buck M and Gutkind JS: Distinct pattern of expression of differentiation and growthrelated genes in squamous cell carcinomas of the head and neck revealed by the use of laser capture microdissection and cDNA arrays. Oncogene 9: 3220-3224, 2000.

32. Villaret DB, Wang T, Dillon D, Xu J, Sivam D, Cheever MA and Reed SG: Identification of genes overexpressed in head and neck squamous cell carcinoma using a combination of complementary DNA subtraction and microarray analysis. Laryngoscope 110: 374-381, 2000.

33. Ono K, Tanaka T, Tsunoda T, Kitahara O, Kihara C, Okamoto A, Ochiai K, Takagi $\mathrm{T}$ and Nakamura Y: Identification by cDNA microarray of genes involved in ovarian carcinogenesis. Cancer Res 60: 5007-5011, 2000

34. Brigstock DR: The connective tissue growth factor/cysteine-rich 61/nephroblastoma overexpressed (CCN) family. Endocr Rev 20: 189-206, 1999.

35. Pennica D, Swanson TA, Welsh JW, Roy MA, Lawrence DA, Lee J, Brush J, Taneyhill LA, Deuel B, Lew M, Watanabe C, Cohen RL, Melhem MF, Finley GG, Quirke P, Goddard AD, Hillan KJ, Gurney AL, Botstein D and Levine AJ: WISP genes are members of the connective tissue growth factor family that are up-regulated in wnt-1-transformed cells and aberrantly expressed in human colon tumors. Proc Natl Acad Sci USA 95: 14717-14722, 1998.

36. Dickson RB and Lippman ME: Estrogenic regulation of growth and polypeptide growth factor secretion in human breast carcinoma. Endocr Rev 8: 29-43, 1987.

37. Zoubine MN, Banerjee S, Saxena NK, Campbell DR and Banerjee SK: WISP-2: a serum-inducible gene differentially expressed in human normal breast epithelial cells and in MCF-7 breast tumor cells. Biochem Biophys Res Commun 282: 421-425, 2001

38. Henderson BE, Ross R and Bernstein L: Estrogens as a cause of human cancer: the Richard and Hinda Rosenthal Foundation award lecture. Cancer Res 48: 246-253, 1988.

39. Liehr JG: Catecholestrogens in the induction of tumors in the kidney of the Syrian hamster. Adv Pharmacol 42: 824-828, 1998.

40. Brinkmann U, Gallo M, Polymeropoulos MH and Pastan I: The human CAS (cellular apoptosis susceptibility) gene mapping on chromosome 20q13 is amplified in BT474 breast cancer cells and part of aberrant chromosomes in breast and colon cancer cell lines. Genome Res 6: 187-194, 1996.

41. Bischoff JR, Anderson L, Zhu Y, Mossie K, Ng L, Souza B, Schryver B, Flanagan P, Clairvoyant F, Ginther C, Chan CS, Novotny M, Slamon DJ and Plowman GD: A homologue of Drosophila aurora kinase is oncogenic and amplified in human colorectal cancers. EMBO J 17: 3052-3065, 1998.

42. Zhang R, Averboukh L, Zhu W, Zhang H, Jo H, Dempsey PJ, Coffey RJ, Pardee AB and Liang P: Identification of rCop-1, a new member of the $\mathrm{CCN}$ protein family, as a negative regulator for cell transformation. Mol Cell Biol 18: 6131-6141, 1998.

43. Perbal B, Martinerie C, Sainson R, Werner M, He B and Roizman $\mathrm{B}$ : The $\mathrm{C}$-terminal domain of the regulatory protein NOVH is sufficient to promote interaction with fibulin $1 \mathrm{C}$ : a clue for a role of NOVH in cell-adhesion signaling. Proc Natl Acad Sci USA 96: 869-874, 1999. 